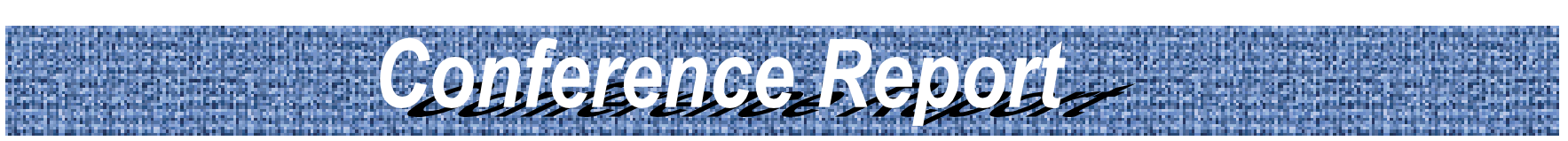

\title{
IEEE Industry Applications Society 45th Annual Meeting (IAS2010) October 3 - 7, 2010, Houston, Texas, USA
}

2010 年 10 月 3 日から 7 日までの 5 日間, IEEE Industry Application Society 2010 Annual Meeting (IAS2010) がアメリ カ, テキサス州のヒューストンにある Hyatt Regency Houston で開催された。この会議は自動制御, 静電気, 鉱業, 金属, 電気設備規格などの幅広い分野をカバーする会議であり, 今年で 45 回目となる。また, 受付で配布されたプログラム 資料によると今年は新しい形態になって 2 年目であり, こ れまで 30 年以上の間決まったスケジュールにて行われてい たが 2009年に Industrial Power Conversion Systems Department に属する 4 つの Technical Committee が Energy Conversion Congress and Exposition（ECCE）に移転したためスケジュー ルが大きく変わったとのこと。確かに会議の構成が Tutorial と Technical Sessionの二本立てに変更され, それに合わせ参 加登録費も Full conference registration, Technical sessions only, Tutorials only の 3 種類に分かれていた。

Tutorial は全部で 12 件行われ，特に Power System 関連の ものが多く見られた。一方, Technical Session は Plenary Session を含めると全部で 22 件あり, 発表は 122 件であった。 Plenary Session では Industrial Automation and Control Committee から 1 件, Power System Engineering Committee か $ら 2$ 件, General Applications in Industry Committee から 1 件, Electrostatic Processes Committee から 1 件の計 5 件の講演が 行われた。風力エネルギーの貯蔵方法, アークフラッシュ に対する保護具選定一の危機管理原則の応用, 電力変換技 術の航空機への応用, 静電気応用技術の発展といった内容 でどの発表も興味深いものであった。Technical Session にお ける各 committee のセッション数は以下のとおりである,

Electrostatic Processes : 6 件, Industrial Automation and Control : 4 件, Metals Industry : 2 件, General Applications of Electrical and Electronic Engineering Industry : 1 件, Power System Protection : 1 件, Power System Engineering : 3 件, Mining : 2 件, Energy Systems : 2 件。セッション数が以前に 比べ少なくなっている理由としては, 上記の Industrial Power Conversion Systems Department の ECCE への移転が大きく 影響しているためであるが，開催場所が昨年と同じという ことも影響したのかもしれない。

3 日目の Awards Dinner and President's Banquet では各種の Award の授与があり, 日本人では安川電機の久米常生氏が Distinguished Lecture に選出された。また, 特に優れた業績 をあげた 35 歳以下の研究者に授与される Andrew W. Smith Outstanding Young Member Award には Dr. Wei Qiao (The University of Nebraska-Lincoln)が選ばれた。驚いたのは, 彼 は研究代表者として U.S. National Science Foundation などか

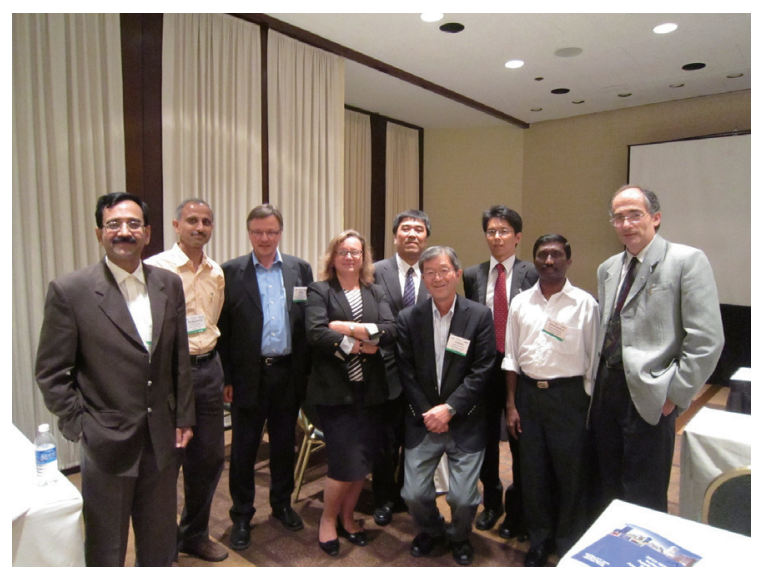

図 1 セッション終了後に部屋に残っていた方々との記念撮 影

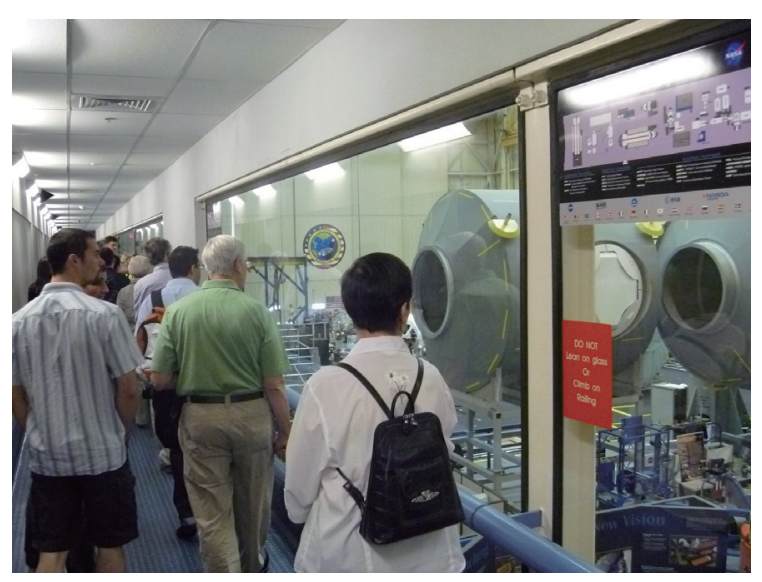

図 2 NASA ッアー（訓練施設見学）の様子

ら\$2.5 million 以上の研究費のサポートを受けているとのこ とで，同じ世代ということもあり非常に刺激を受けた。

今回は学会主催の見学会として 1 日目に NASA Johnson Space Center ヘッアーと4 日目のSan Marcosにある Thermon 社の工場へのツアーが企画されていた。1 日目は比較的時間 に余裕があったため, 著者は NASA ツアーに参加した。 NASA ツアーに参加したのは約40名でNASA Johnson Space Center ではトラムに乗りながら施設間を移動し, スペースシ ヤトルなどの運用管制センターや訓練施設を見学した。 次回は 2011 年 10 月 9 日〜 13 日にアメリカ, フロリダ州 のオーランドにある Walt Disney World Swan Hotel で開催予 定である。観光地としても人気がある場所であり, 参加者 が増え，今回の会議以上に盛り上がることを期待したい。

黒木 智之 (大阪府立大学)

(平成 22 年 10 月 15 日受付) 